\title{
Quantitative Expression of Candidate Genes for Developmental Competence in Bovine Two-Cell Embryos
}

\author{
MARGOT ALVES NUNES DODE, ${ }^{1}$ ISABELLE DUFORT, ${ }^{2}$ LYNE MASSICOTTE, ${ }^{2}$ \\ AND MARC-ANDRÉ SIRARD ${ }^{2 *}$ \\ ${ }^{1}$ Embrapa Recursos Genéticos e Biotecnologia, Brasılia, DF, Brazil \\ ${ }^{2}$ Centre de Recherche en Biologie de la Reproduction, Département des Sciences Animales, Université Laval, Québec, \\ Quebec, Canada
}

\begin{abstract}
Only competent oocytes are able to undergo complete maturation and normal embryonic development. Therefore, the identification of genes that are differentially expressed in competent oocytes would contribute to our understanding of the factors controlling competency. It is well known that time of cleavage after insemination in vitro is highly correlated with embryonic developmental potential and this can be used to distinguish between oocytes of different quality. The main objective of this study was to identify genes associated with competency and rapid cleavage. We examined the expression of 16 candidate genes (IDH, YEAF Cathepsin B, RAD50, TCP1 NCOR1, HUEL, STK6, ZNF403, AOP2, EEF1A1, Hsp90, Hsp40, AKR1B1, PGRMC1, and DMRT2) in early and late cleaving embryos, by real time PCR. These transcripts were derived from previous study in our laboratory using cDNA coming from a suppressive subtraction hybridization ( $\mathrm{SSH}$ ) between early cleaving versus late cleaving embryos spotted on a microarray slide. Of the 16 genes evaluated, 3 (IDH, YEAF, and $\mathrm{H} 2 \mathrm{~A})$ showed statistical difference $(P<0.05)$ between early and late cleaving embryos. However, some genes such as Cathepsin B $(P=0.0677)$, RAD50 ( $P=$ 0.0899), and TCP1 $(P=0.0824)$ tended to show higher expression in the early cleaving than in the late cleaving embryo. In conclusion, we have identified three genes (YEAF, IDH, H2A) that were differentially expressed in the early cleaving embryos, and their expression can be associated with greater developmental competence. Mol. Reprod. Dev. 73: 288297, 2006. ๑ 2005 Wiley-Liss, Inc.
\end{abstract}

Key Words: cleavage time; mRNA; cattle; gene expression

\section{INTRODUCTION}

Although substantial progress has been made in procedures for in vitro maturation, fertilization, and culture of bovine oocytes, the percentage of embryos that are able to demonstrate normal development is still lower in oocytes matured in vitro than in those matured in vivo.
Abundant evidence has been presented over the last decade indicating that the developmental potential of embryos in vitro is, ultimately, dependent on the quality of the oocyte from which it originates (for reviews see Lonergan et al., 2003; Sirard et al., 2003). It is well established that only competent oocytes have the ability to develop normally. This competence is progressively acquired during late folliculogenesis, through a range of cellular and molecular attributes that provides the oocyte with the ability to complete meiosis, insure monospermic fertilization, decondense the sperm head, proceed through maternal-zygote transition, and undergo pre-implantation development (for review see Coticchio et al., 2004). Therefore, when immature oocytes are removed from their follicles, they have to be able to undergo not only nuclear and cytoplasmic, but also molecular maturation, which has been considered as an invisible subset of cytoplasmic maturation (Sirard, 2001).

A common feature during oocyte growth, is its high level of transcription, reflecting the importance of the accumulation of maternal mRNA and proteins, especially for embryonic development (for review see Song and Wessel, 2005). In large mammals, the oocyte must accumulate all of the necessary maternal factors during folliculogenesis in preparation for the post-fertilization events. This critical role of the oocyte until the maternalzygote transition (MZT), which is when the embryonic genome will become functionally active, can be ascertained by the fact that, during this period, the early embryo has to rely on post-transcriptional regulatory mechanisms to control development (for review see Rodriguez and Farin, 2004). This leads to the assump-

Grant sponsor: Natural Sciences and Engineering Research Council of Canada (NSERC); Grant sponsor: Conselho Nacional de Desenvolvimento Científico e Tecnológico, CNPq.

*Correspondence to: Marc-André Sirard, Centre de Recherche en Biologie de la Reproduction, Département des Sciences Animales, Université Laval, Québec, Canada, G1K 7P4.

E-mail: Marc-Andre.Sirard@crbr.ulaval.ca

Received 5 August 2005; Accepted 6 October 2005

Published online 16 December 2005 in Wiley InterScience

(www.interscience.wiley.com).

DOI $10.1002 / \mathrm{mrd} .20427$ 
tion that oocyte competency may be encoded in the constituency and abundance of specific transcripts in their mRNA pools, which were stored during oocyte growth and the final phase of folliculogenesis.

There is a clear relationship in cattle between the time of first cleavage post insemination in vitro and developmental competence, being those oocytes that cleaved earlier after IVF, most likely to reach the blastocyst stage than their late-cleaving counterparts (Dinnyes et al., 1999; Lonergan et al., 1999; Lequarre et al., 2003; Favetta et al., 2004; Gutierrez-Adan et al., 2004). Moreover, the time of first cleavage has been also related to the polyadenylation status of several developmentally important gene transcripts (Brevini et al., 2002) and to differences in gene expression (Lonergan et al., 2000; Ward et al., 2001; Fair et al., 2004).

Since it is well known that the time of first cleavage division after in vitro insemination, is highly correlated with the ability of the embryos to reach the blastocyst stage, selecting embryos on the basis of time of first cleavage provides us an interesting model to study oocytes with different competency. If maternal mRNA stock contributes to developmental competency at MZT, differences in mRNA abundance between the early and late cleaving embryos could be expected at the two cell stage.

Efforts to identify potential markers for bovine oocyte competence have been made using oocytes from different sizes of follicles (Robert et al., 2000; Donnison and Pfeffer, 2004), as well as oocytes that cleaved at different times after in vitro fertilization (Fair et al., 2004). Although some genes were identified as being related to competence, there is no consensus about which gene or genes could be used as specific markers.

In an attempt to identify genes associated with oocyte competence we use the time of first cleavage to evaluate oocytes with different competency. We compared the abundance of transcripts of 16 genes in zygotes that cleaved at 24-32 hr post-insemination (hpi) (early cleavage) and 36-44 hpi (late cleavage). The gene selection was based on previous studies in our laboratory, in which we have used cDNA coming from a SSH library between early cleaving versus late cleaving embryos spotted in a microarray slide (Sirard, unpublished results).

Our objective was to measure mRNA levels of these genes as an indication of their possible role in oocyte competence. The identification of genes that are more expressed in competent oocytes would contribute to our understanding of the factors controlling developmental competence.

\section{MATERIALS AND METHODS}

All chemicals were obtained from Sigma-Aldrich (St. Louis, MO) unless otherwise stated.

\section{Oocytes Recovery and Selection}

Bovine ovaries were collected at a commercial slaughterhouse and transported to the laboratory in saline solution $(0.9 \% \mathrm{NaCl})$ containing antimycotic agent, at
$30-32{ }^{\circ}$ C. Cumulus-oocyte complexes (COCs) were aspirated from 3 - to 6 - $\mathrm{mm}$ follicles with an 18-guage needle attached to a $10-\mathrm{ml}$ syringe. Healthy COCs with at least three layers of cumulus were selected for in vitro maturation and fertilization.

\section{In Vitro Maturation}

After selection COCs were washed three times in HEPES-buffered Tyrode lactate medium (TLH) supplemented with $0.3 \%$ bovine serum albumin (BSA) fatty acid free (FAF), $0.2 \mathrm{mM}$ pyruvic acid, and $50 \mu \mathrm{g} / \mathrm{ml}$ gentamicin, and then were transferred to the maturation medium.

Groups of 10 COCs were placed in droplets of media under mineral oil. Each droplet consisted of $50 \mu \mathrm{l}$ of maturation medium composed of modified synthetic oviductal fluid (SOF) medium [40] with $0.8 \%$ BSA-FAF, modified Eagle medium (MEM) nonessential amino acids (Gibco BRL, Burlington, ON, Canada), MEM essential amino acids (Gibco), supplemented with $1 \mathrm{mM}$ glutamine, $0.1 \mu \mathrm{g} / \mathrm{mL}$ FSH, $1 \mu \mathrm{g} / \mathrm{ml} 17 \exists$-estradiol, and $50 \mu \mathrm{g} / \mathrm{ml}$ gentamicin. The droplets containing COCs were incubated in a humidified atmosphere for $24 \mathrm{hr}$ at $38.5^{\circ} \mathrm{C}$ with $5 \% \mathrm{CO}_{2}$ in air.

\section{In Vitro Fertilization (IVF)}

For in vitro fertilization, groups of five matured COCs were added to a $48-\mu$ d droplets of IVF media under mineral oil. The droplets were composed of modified TLH medium supplemented with $0.6 \%$ BSA FAF, $0.2 \mathrm{mM}$ pyruvic acid, $10 \mu \mathrm{g} / \mathrm{ml}$ heparin, and $50 \mu \mathrm{g} / \mathrm{ml}$ gentamycin.

Prior to transfer to the IVF droplets, the COCs were washed twice in TLH medium. Once transferred, $2 \mu \mathrm{l}$ of PHE (1 $\mathrm{mM}$ hypotaurine, $2 \mathrm{mM}$ penicillamine, and $250 \mathrm{mM}$ epinephrine) were added to each droplet $10 \mathrm{~min}$ before semen was added. The semen used consisted of a cryopreserved mixture of ejaculates from three bulls (Centre d'Insemination Artificielle du Quebec, St-Hyacinthe, Que., Canada). The semen was thawed in $37^{\circ} \mathrm{C}$ water for $1 \mathrm{~min}$, added on a discontinuous Percoll gradient ( $2 \mathrm{ml}$ of $45 \%$ Percoll over $2 \mathrm{ml}$ of $90 \%$ Percoll) and centrifuged at $700 \mathrm{~g}$ for $30 \mathrm{~min}$ at $26^{\circ} \mathrm{C}$. The pellet was resuspended in $1 \mathrm{ml}$ of TLH medium and centrifuged at $250 \mathrm{~g}$ for $5 \mathrm{~min}$ at $26^{\circ} \mathrm{C}$. The supernatant was discarded and the spermatozoa were resuspended in IVF medium after being counted on a hemocytometer to obtain a final concentration of $1 \times 10^{6}$ cells $/ \mathrm{ml}$. Finally, $2 \mu \mathrm{l}$ of the sperm suspension were added to each droplet and the incubation took place in a humidified atmosphere at $38.5^{\circ} \mathrm{C}$ in $5 \% \mathrm{CO}_{2}$ in air, for $15-18 \mathrm{hr}$.

\section{In Vitro Culture}

Following fertilization, presumptive zygotes were mechanically denuded by repeated pipetting, washed three times in PBS containing 0.3\% BSA-FAF and transferred to culture droplets $(50 \mu \mathrm{l})$ in groups of 20 30 embryos. Embryo in vitro culture (IVC) was performed in modified synthetic oviduct fluid under mineral oil at $38.5^{\circ} \mathrm{C}$ in $5 \% \mathrm{CO}_{2}$ in a reduced oxygen atmosphere 
(7\%) with high humidity, as previously described (Ali and Sirard, 2002).

To identify the populations of two cell-embryos that differ in competence in our IVF system, a preliminary experiment was done in which, the dishes were examined at 24, 28, 30,32, 34, 36, and 44 hpi (three replicates). The two-cell embryos were removed in each time point and transferred into a new IVC droplets, and were cultured separately until the blastocyst stage.

Three populations of two-cell embryos were identified, those that cleaved between 24 and $32 \mathrm{hr}$ (early cleavage), from 32 to $36 \mathrm{hpi}$ (intermediate cleavage) and those from 36 to 44 hpi (late cleavage).

To collect the embryos for gene quantification, dishes were examined at 24, 32, 36, and $44 \mathrm{hpi}$. Embryos that cleaved between 24 and 32 hpi and those that cleaved between 36 and 44 hpi were removed from culture and collected in groups of 10 in small volumes of PBS, frozen and stored at $-80^{\circ} \mathrm{C}$ until RNA extraction.

All two-cell embryos pools were collected from three different fertilization replicates.

\section{RNA Extraction and cDNA Preparation}

All pools of two-cells embryos were spiked with $1 \mathrm{pg}$ of exogenous GFP RNA containing a poly(A) tail, before RNA extraction, as described previously (Vigneault et al., 2004). Thus, the RNA extractions of the embryo pools containing GFP were performed using the Rneasy Kit (Qiagen, Mississauga, Ontario, CA) as recommended by the manufacturer and eluted twice in $30-\mu \mathrm{l}$ of warm $\left(60^{\circ} \mathrm{C}\right)$ elution buffer. The RNA extraction procedure included a DNase I treatment to remove genomic DNA.

The reverse transcription was performed using a Sensiscript Reverse Transcriptase Kit (Qiagen). A denature step to remove secondary structures was performed by incubating the RNA for $5 \mathrm{~min}$ at $65^{\circ} \mathrm{C}$ and then rapidly placed on ice for $3 \mathrm{~min}$.

\section{Gene Selection}

We have used cDNA coming from a SSH library between early cleaving versus late cleaving embryos spotted in a microarray slides. The clones resulting in high differential ratio were selected to assess their predictive value. The genes selected are involved in transcription (YEAF [RYBP (RING1 and YY1 binding protein], NCOR1 [nuclear receptor co-repressor 1], HUEL [Solute carrier family 30 (zinc transporter) member 9 (SLC30A9)], ZNF403 [zinc finger protein 403]), DNA repair (RAD50 [RAD50 homologue S. cerevisiae]), translation (STK6 [Serine/threonine kinase 6], EEF1A1 [eukaryotic translation elongation factor 1 alpha 1]), protein regulation (Cathepsin B), chaperoning activity (TCP1 [(CCT2) (Chaperonin containing TCP1, subunit 2-beta)], Hsp40 [DNAJA1(DnaJ (Hsp40) homolog, subfamily A, member 1)], Hsp90 [Heat shock protein 90 alpha]), cell signaling (AKR1B1 [Aldose reductase] PGRMC1 [Progesterone receptor membrane component 1]) and differentiation (DMRT2 [doublesex- and mab-3-related transcription factor 2]).
In addition to those, two more genes involved in oxidative stress defense (IDH and AOP2), were also selected to be quantified. The selection was also based on a previous study carried out in our laboratory, using a $2 \mathrm{D}$ gel electrophoresis to identify potential proteins implicated in developmental competence (Sirard, unpublished results).

\section{Real-Time Polymerase Chain Reaction (Q-PCR)}

The primers for each gene were designed using Primer3 web interface. The sequences, the size of amplified product, the GenBank accession number as well as the annealing temperature, are presented in Table 1. For each gene examined, a standard curve, consisting of PCR products purified with the QIAquick PCR Purification Kit (Qiagen), quantified with a spectrophotometer and sequenced to validate the amplified product, was included in the run. The standard curve consisted of four standards of the purified PCR products diluted from $0.1 \mathrm{pg}$ to $0.1 \mathrm{fg}$. Real-time PCR was executed on a Lightcycler apparatus (Roche Diagnostics, Laval, Que., Canada) using SYBR green.

The PCR reaction consisted of cDNA equivalent to a single embryo, $0.5 \mu \mathrm{l}$ of $10 \mu \mathrm{M}$ of each primer, $1.6 \mu \mathrm{l}$ of $25 \mathrm{mM} \mathrm{MgCl}_{2}, 2 \mu \mathrm{l}$ of the SYBR green mix containing dNTPs, FastStart DNA polymerase enzyme, and $13.4 \mu \mathrm{l}$ of buffer (Roche). The PCR conditions used were: 1 denaturing cycle of $10 \mathrm{~min}$ at $95^{\circ} \mathrm{C}, 50 \mathrm{PCR}$ cycles (denaturing: $95^{\circ} \mathrm{C}$ for $5 \mathrm{sec}$; annealing temperature [see Table 1] for 5 sec; extension: $72^{\circ} \mathrm{C}$ for 20 sec) followed by a melting curve. The Lightcycler Software Version 3.5 (Roche) was used to quantify and analyze the results. The GFP quantity obtained for each pool was used to correct the values obtained for each gene (Vigneault et al., 2004). These calculations compensate for experimental errors caused by the technique or the materials used for the RNA extraction and reverse transcription. The Q-PCR product specificity was confirmed by analysis of the melting curve given by the Lightcycler software (Roche). The products were then electrophoresed on an agarose gel for single product confirmation.

\section{Statistical Analysis}

Normalization of the results obtained for individual genes (triplicates), within each pool of cDNA, was performed by calculating each as a ratio to the level of GFP RNA. Data are presented as mean \pm SEM. A nonparametric two-tailed $t$-test was used for the evaluation of difference on the mRNA level between each time of cleavage. Differences were considered statistically significant at the $95 \%$ confidence level $(P<0.05)$.

The data of embryo development were evaluated using a chi-square analysis and were considered significantly different at $P<0.05$.

\section{RESULTS}

To study the expression of genes related to the oocyte competence we selected embryos on the basis of time of 
TABLE 1. Information and Sequence of Specific Primers Used for Amplification in Real Time PCR

\begin{tabular}{|c|c|c|c|c|}
\hline Genes & Oligos sequences & $\begin{array}{l}\text { GenBank } \\
\text { accession number }\end{array}$ & $\begin{array}{l}\text { Size of PCR } \\
\text { product (bp) }\end{array}$ & $\begin{array}{c}\text { Annealing } \\
\text { temperature }\left({ }^{\circ} \mathrm{C}\right)\end{array}$ \\
\hline$T C P 1$ & $\begin{array}{l}\text { Up 5'-CTTCACTAGTTCTGGATGGTCAAAG-3' } \\
\text { Low 5'-GAGGTTGATTCTACAGCAAAGGTT-3' }\end{array}$ & AF026166 & 258 & 58 \\
\hline STK6 & $\begin{array}{l}\text { Up 5 5'-CTCTGAGTCCATCTTCCATGAG-3' } \\
\text { Low } 5^{\prime} \text {-GGTGCTTTGCTATGAGTTCCTC-3' }\end{array}$ & BC027464 & 212 & 55 \\
\hline HUEL & $\begin{array}{l}\text { Up 5'-TAGTCTTGGCAAACTTGGTTCC-3' } \\
\text { Low 5'-AGGCAGAAGTAGATTTCGATGG-3' }\end{array}$ & BC016949 & 292 & 55 \\
\hline Hsp90 & $\begin{array}{l}\text { Up 5'-GTATGGACAATGACTCCAATCAAGT-3' } \\
\text { Low5'-CCGTTTGTTGTAAGGTGTGTATGTA- } 3^{\prime}\end{array}$ & $\mathrm{AB} 027464$ & 277 & 55 \\
\hline$A K R 1 B 1$ & $\begin{array}{l}\text { Up 5'-GTCTCCAACTTCAACCATCTCC-3' } \\
\text { Low 5'-CCTCCTTGTCCAGTTCAAAGTC-3' }\end{array}$ & M31463 & 379 & 55 \\
\hline$C T S B$ & $\begin{array}{l}\text { Up } 5^{\prime} \text {-TAGAAGGATCACAGCAAGGACA-3' } \\
\text { Low } 5^{\prime} \text {-GCGAGACCTTAAAGGGTTTGTA-3' }\end{array}$ & NM_174031 & 227 & 55 \\
\hline$H s p 40$ & $\begin{array}{l}\text { Up 5'-GAGGTCTGACACTGAACACCAC- } 3^{\prime} \\
\text { Low } 5^{\prime} \text {-CTGCCTGAGAGGAAGGAAGTAG-3' }\end{array}$ & D13388 & 155 & 56 \\
\hline ZFP 403 & $\begin{array}{l}\text { Up 5'-GCAGCCACACAACTAAAGACAC-3' } \\
\text { Low 5'-TACCGACAGCATCTGAAGGAG-3' }\end{array}$ & AF126964 & 304 & 56 \\
\hline PGRMC1 & $\begin{array}{l}\text { Up 5'-AATCATGCAGTTAGGTCAATCG- } 3^{\prime} \\
\text { Low } 5^{\prime} \text {-TGTGTGTCACAAATCCAGAAAG-3' }\end{array}$ & AF254804 & 265 & 54 \\
\hline$E E F 1 A 1$ & $\begin{array}{l}\text { Up } 5^{\prime} \text {-TCTTGTCCACTGCTTTGATGAC-3' } \\
\text { Low 5' } 5^{\prime} \text {-AGCTGAAGGAGAAGATTGATCG-3' }\end{array}$ & AJ238405 & 210 & 56 \\
\hline NRCO1 & $\begin{array}{l}\text { Up 5'-TGTTTGGACTGACCATGAGAAG-3' } \\
\text { Low 5'-AATTTGCTGGTTTCTCCCTCTG-3' }\end{array}$ & NM_006311 & 203 & 54 \\
\hline$R A D 50$ & $\begin{array}{l}\text { Up 5'-CAGAATGTGAACAGAGACATACAGC-3' } \\
\text { Low 5'-CTGAACACTTCGATCCAAATCTAGT-3' }\end{array}$ & AF057300 & 216 & 56 \\
\hline$D M R T 2$ & $\begin{array}{l}\text { Up 5'-GAGACATGAGTGATGGCAGATG-3' } \\
\text { Low 5'-ACCCAGGGAGTGTTTAGTCAAG-3' }\end{array}$ & BC030204.1 & 174 & 56 \\
\hline YEAF1 & $\begin{array}{l}\text { Up 5'-ACACAAGAACAGAACTGCTTGC-3' } \\
\text { Low 5' } 5^{\prime} \text {-TTTCACCTGCCTTATCAAGACC-3' }\end{array}$ & $\mathrm{AB} 029551$ & 195 & 56 \\
\hline$I D H 1$ & $\begin{array}{l}\text { Up 5'-TCATAGGTCGTCATGCTTATGG-3' } \\
\text { Low 5'-GACAAAGCCATCTGGAAAGAAC-3' }\end{array}$ & NM_181012 & 220 & 56 \\
\hline$A O P 2$ & $\begin{array}{l}\text { Up 5'-GATCACAGCCAAGGTCTTTAGG-3' } \\
\text { Low 5'-ACCCTGCAGAGATCCAAGTAAG-3' }\end{array}$ & NM_174643 & 173 & 56 \\
\hline$H 2 A$ & $\begin{array}{l}\text { Up 5'-GTCGTGGCAAGCAAGGAG-3' } \\
\text { Low 5'-GATCTCGGCCGTTAGGTACTC-3' }\end{array}$ & NM_013549 & 181 & 57 \\
\hline$G A P D H$ & $\begin{array}{l}\text { Up 5'-CCAACGTGTCTGTTGTGGATCTGA-3' } \\
\text { Low 5'-GAGCTTGACAAAGTGGTCGTTGAG-3' }\end{array}$ & XM_598051 & 237 & 60 \\
\hline$\beta$-Actin & $\begin{array}{l}\text { Up 5'-CGTGACATTAAGGAGAAGCTGTGC-3' } \\
\text { Low 5'-CTCAGGAGGAGCAATGATCTTGAT-3' }\end{array}$ & NM_001101 & 374 & 56 \\
\hline
\end{tabular}

first cleavage. To determine the time to select the early and late cleaving embryos, which would reflect oocytes with different competency in our system, a pre-experiment was carried out to verify developmental potential of embryos cleaved at different times post insemination.

The results from kinetics of cleavage and blastocyst yield in our IVF system are presented in Figure 1 . When all the time points were considered, the highest proportion of oocytes cleaved was observed at 30 and $32 \mathrm{hpi}$ $(P<0.05)$. In the interval between 36 to 44 hpi, cleavage is also high, but represents a much larger time interval (Fig. 1A). A significantly higher proportion $(P<0.05)$ of blastocysts was also observed in the oocytes that cleaved at 30 and 32 hpi (Fig. 1B).

When the time points were grouped into $24-32,32-$ 36, and 36-44 hpi, an important proportion (47.1\%) of the oocytes had cleaved between 24 and 32 hpi (Fig. 1C), also being the one that had the highest blastocyst rate (Fig. 1D). The blastocysts from this group accounts for $57.9 \%$ of all blastocysts obtained in the experiment, representing the most competent oocytes in terms of developmental ability. The cleavage and blastocyst rates were similar for the oocytes that cleaved between 32-36 hpi and those that cleaved at 36-44 hpi, being lower than the rate observed for the group that cleaved at $24-32 \mathrm{hpi}(P<0.05)$. The very early-cleaved oocytes, before $24 \mathrm{hpi}$, were excluded not only because they were in a very low number (18/475), but also because they were less capable $(P<0.05)$ of further development than the other groups.

These results allowed us to identify three populations of two-cell embryos, the early (24-32 hpi), intermediate (32-36 hpi), and late cleaving embryos (36-44 hpi), which were used for gene quantification. The abundance of each gene transcript studied in each group of two-cells embryos is presented in Figures 2 and 3.

The quantification of the levels of $\mathrm{H} 2 \mathrm{~A}$ was done as a control, however unexpectedly the mRNA level was significantly lower $(P<0.05)$ in the late cleaving embryos than in early cleaved embryos (Fig. 2). To confirm that the lower expression observed for H2A was due to the difference in competence and not due only to degradation, we quantified the expression of two other housekeeping genes, $\beta$-actin and glyceraldehyde 3 - 
A
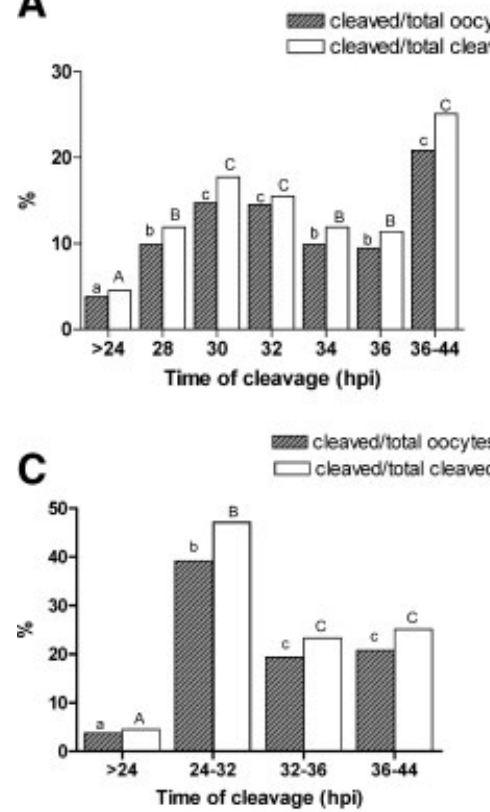

Fig. 1. Blastocyst and cleavage rate of bovine oocytes that cleaved at different time after in vitro insemination (hpi). Data are from three replicates. When all the time points were considered, the highest proportion of oocytes cleaved was observed at 30 and $32 \mathrm{hpi}$ and in the interval between 36 and 44 hpi. A: A higher proportion of blastocysts

phosphate dehydrogenase (GAPDH). The expression of both genes, $\beta$-actin and GAPDH, was similar $(P>0.05)$ in early and late cleaving embryos (Fig. 3).

From the 16 genes selected, only IDH, H2A, and YEAF showed statistical differences $(P<0.05)$ between early and late cleaving embryos. However, some genes such as
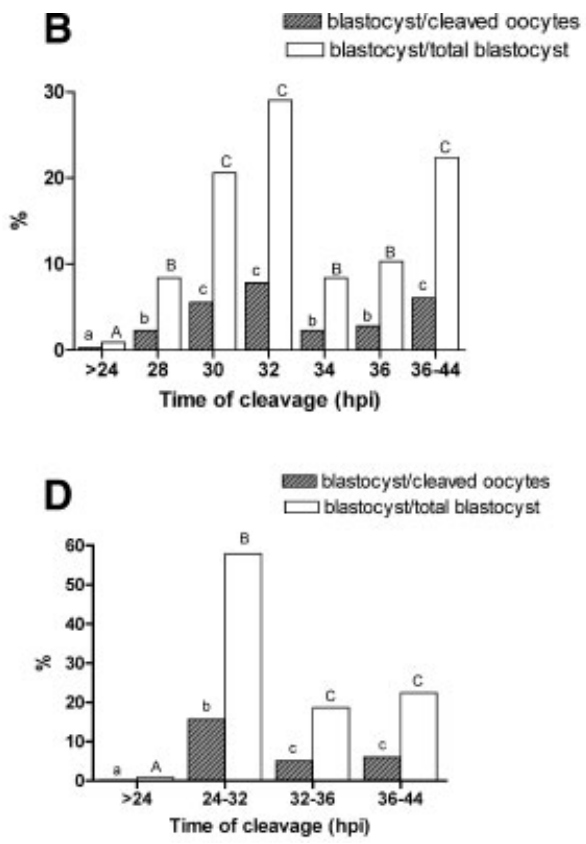

was also observed in those two groups of oocytes. B: When the time points were grouped a higher cleavage $(\mathbf{C})$ and blastocyst rate $(\mathbf{D})$ were observed in oocytes cleaved between 24 and 32 hpi. Bars with different superscripts within time of cleavage, are significantly different $(P<0.05)$ by Chi-square analysis.

Cathepsin B $(P=0.0677)$, RAD50 $(P=0.0899)$, and TCP1 $(P=0.0824)$ showed at least $30 \%$ higher expression in the early cleaving than in the late cleaving embryos (Fig. 2).

No change in transcript level between the two groups was seen for the NCOR1, HUEL, STK6, ZNF403, AOP2,
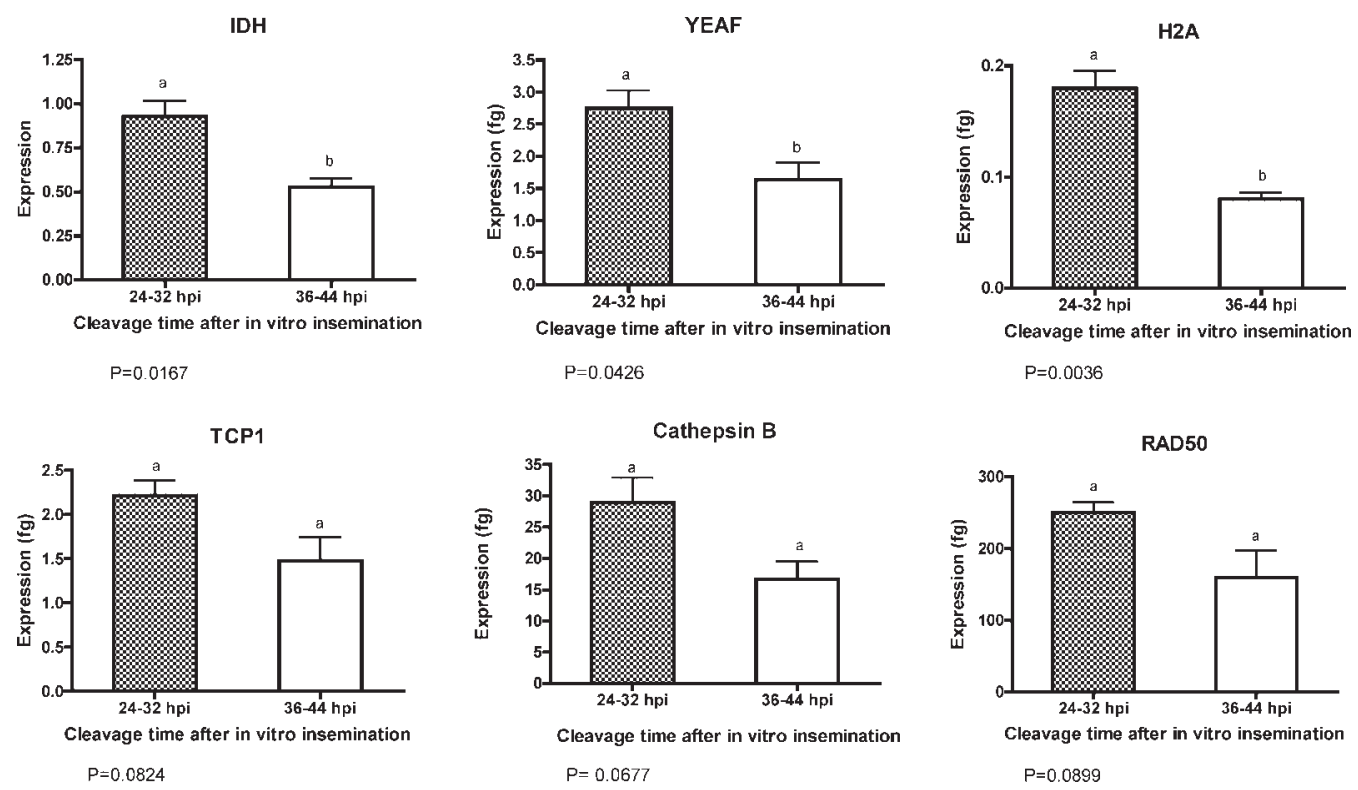

Fig. 2. Transcript levels of various genes by Q-PCR that showed differential expression $(P<0.05$ and $P<0.10$ ) in two cell embryos that cleaved between 24 and 32 hpi (early cleavage) and between 36 and 44 hpi (late cleavage). ${ }^{\mathrm{a}, \mathrm{b}}$ Different superscript over the bars indicates significantly different $(P<0.05)$ by $t$-test analysis. 

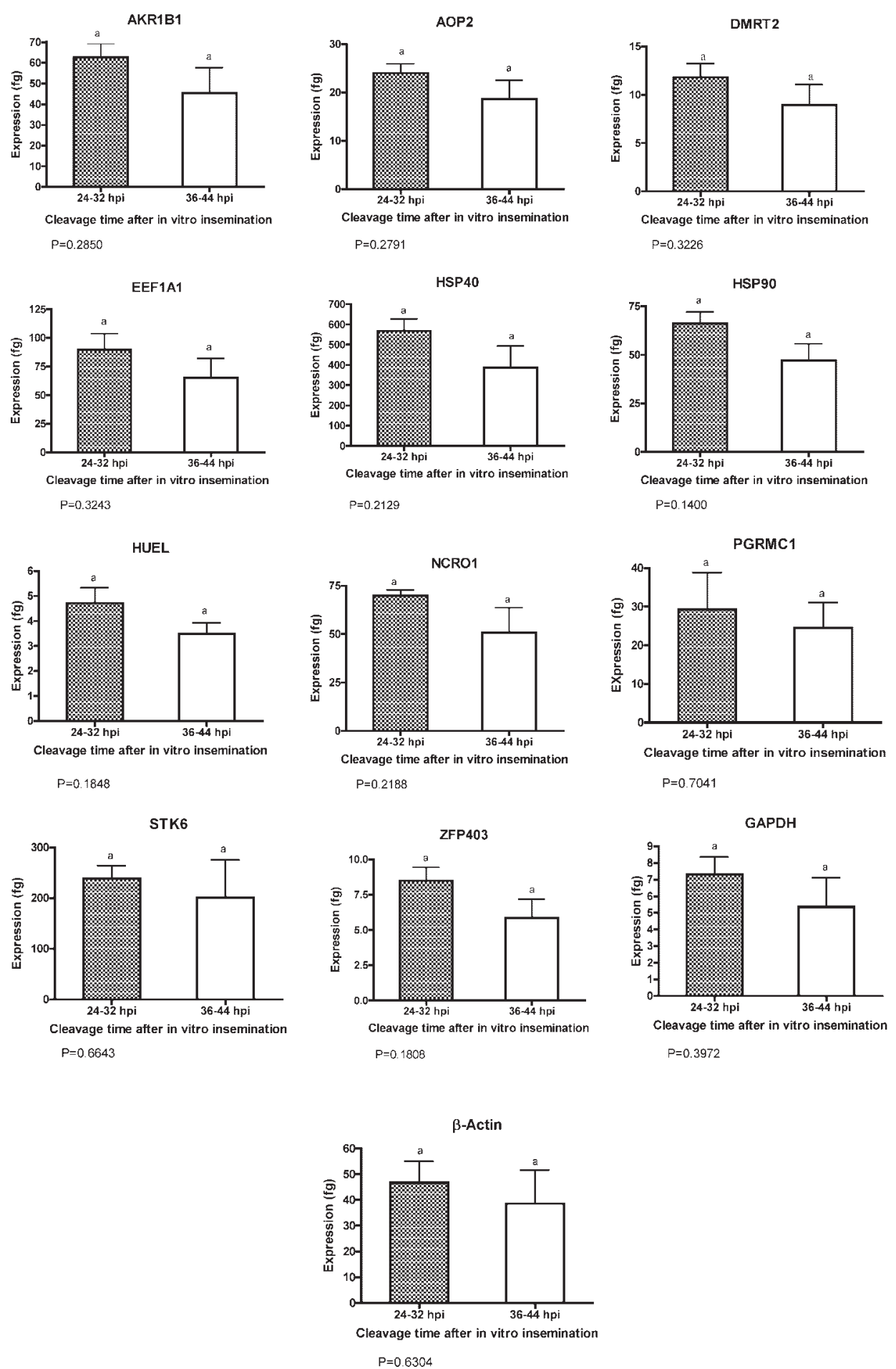

Fig. 3. Transcript levels of various genes by Q-PCR, that showed similar $(P>0.05)$ expression in two cell embryos that cleaved between 24 and 32 hpi (early cleavage) and between 36 and 44 hpi (late cleavage). Results were presented as mean $\pm \mathrm{SEM}$ and analyzed by $t$-test.

EEF1A1, Hsp90, Hsp40, AKR1B1, PGRMC1, and DMRT2 genes (Fig. 3).

\section{DISCUSSION}

It is well established that the time of the first cleavage is highly correlated with the ability to develop to the blastocyst stage. In fact, it has been suggested that deficiency or imbalance of some molecules could accelerate or delay first cleavage, affecting subsequent embryo viability (Dinnyes et al., 1999). In the present study, we used timing of cleavage to represent oocytes with different developmental competencies. 
We evaluated the expression of 16 genes that were selected due to their possible involvement in oocyte competency. According to the results, we can classify the genes as having lower expression $(P<0.05)$ in the late cleaving embryos, those that showed a tendency to be less expressed in late cleaving $(P<0.10)$ and those that were not different $(P>0.10)$ between the two groups. Regardless of the category in which they were classified, the general pattern was a slight decrease in gene expression in the late cleaving embryos. It is possible that in the late cleaving embryos a gradual degradation of maternal mRNA has begun in some fertilized oocytes, this decrease could be one of the factors responsible for their low developmental competence. In addition, it has been shown that low competence seems to be accompanied by altered polyadenylation patterns (Brevini-Gandolfi et al., 1999; Brevini et al., 2002). As pointed out by Brevini et al. (2002) maternal RNA degradation and polyadenylation are both affected in developmentally defective embryos. If it is true that degradation has begun in the low competence embryos, this should be taken into account when the comparison of gene expression is made between embryos of different quality.

We quantified the levels of H2A as a control and, unexpectedly, we found that the levels of mRNA were higher in the early cleaving than in the late cleaving embryos. The mRNA expression of histone H2A was found constant during all the stages of embryo development in bovine (Robert et al., 2002; McGraw et al., 2003) and mouse (Jeong et al., 2005), for that reason it has been used as a housekeeping gene. These studies were carried out to compare the histone transcript levels throughout preimplantation development and, to our knowledge, no quantification of H2A transcripts using oocyte or embryos at the same stage but with different quality, has been reported. Previously, Fair et al. (2004)), who also investigated genes related to oocyte competence and using early and late two-cell embryo, found that histone H3A was the only gene more abundant in early cleaving than in the late cleaving embryos. Moreover, the levels of steam loop binding protein (SLBP) mRNA were higher in competent oocytes (Donnison and Pfeffer, 2004) compared with the incompetent oocytes obtained from different follicle size. These results indicate that the differential expression of H2A is possibly related to competence and not to degradation. To investigate if the same pattern would occurs for other housekeeping genes we measured $\beta$ actin and GAPDH mRNA, however no significant changes were observed between late and early cleaving embryos. Similarly, other studies have reported that the levels of $\beta$-actin transcripts is not related to developmental competence (Brevini-Gandolfi et al., 1999; Brevini et al., 2002).

In contrast to somatic cells in which the levels of histone mRNA and DNA replication are tightly coupled and have little or no capacity to store histone proteins, the oocyte stores histone mRNA as well as protein during oogenesis (Marzluff and Duronio, 2002; Sanchez and Marzluff, 2004). Those maternal stores serve as the source of histones for the early embryos, since they are required to replace the protamines of the sperm nucleus and to assemble embryonic DNA into chromatin. Therefore, the early embryo must contain sufficient stores of maternal histone mRNA and proteins to support chromosome replication (three to four times) until the embryo becomes transcriptionally active (Marzluff and Duronio, 2002). Taken these results together we can speculate that since histones are critical for the postfertilization events, deficient levels could affect first cleavage and consequently, the subsequent embryo development. Therefore, histone levels could be used as markers for competence, when using different populations in the same stage of development, instead of being used as control.

We demonstrated that YEAF was differently expressed in competent versus incompetent 2-cell embryos. It has been suggested that YEAF may play a relevant role in mammals cells acting as a transcriptional repressor. YEAF interacts directly in vivo and in vitro with YY1 (Sawa et al., 2002), which is well known for its capacity to bind DNA and to promote transcription. Studies in our laboratory have shown that the YY1 expression in bovine oocytes and embryos decreases during maturation, and then stays stable from MII to 4-cell stage, declining again at the 8-cell stage (Vigneault et al., 2004). These results suggested that in the bovine, YY1 is probably translated during maturation and can be involved in MZT. Additionally, YEAF interacts directly with other proteins, specially of the mammalian Polycomb complex, to act as a transcription repressor (Garcia et al., 1999). Recently, it has also been reported that an over expression of YEAF transcripts induced cell death in tumor cells, but not in normal cells (Danen-van Oorschot et al., 2004). The role of this gene during oocyte maturation and/or early embryo development in the bovine has not yet been reported.

$\mathrm{IDH}$ is a $\mathrm{NADP}^{+}$-dependent isocytrate dehydrogenase that catalyzes a key regulatory step the in tricarboxylic acid cycle (TCA) (Jennings et al., 1994). In this study not only the protein (Sirard, unpublished results) was present in a higher quantity in the early cleaving embryos but also the mRNA, which confirms the importance of the expression of the gene. In fact, the enzyme activity and the use of specific oxidative substrates have indicated a major participation of the TCA cycle in the process of bovine oocyte maturation (Cetica et al., 2003). Besides its importance in such basic functions on the cell enzymatic machinery, IDH has an important role in the cellular defense against oxidative stress (Sun et al., 1999; Lee et al., 2002). Moreover, IDH also plays a critical role in fat and cholesterol biosynthesis (Koh et al., 2004) and in supplying reduction equivalents and/ or energy required for capacitation and the acrosome reaction in cryopreserved bovine spermatozoa (Cordoba et al., 2005). Reactive oxygen species ROS exert a powerful oxidant potential on cellular molecules such as proteins, lipids and nucleic acids and can be a major cause of cell damage. Since oocytes and embryos are 
exposed to various conditions that cause oxidative stress during in vitro culture, it is expected that those that have better machinery to protect against this stress will have a better chance to develop normally. These could explain the higher levels, not only of the transcripts, but also the presence of the protein in the embryos with higher developmental capacity.

Although not statically different, the transcripts levels for Cathepsin B $(P=0.0677), \operatorname{RAD50} \quad(P=$ $0.0899)$, and TCP1 $(P=0.0881)$ genes, were at least $30 \%$ more abundant in the early two-cell embryos than in late two-cell embryos. It is possible that the number of replicates $(n=3)$ and the variation among replicates could be responsible for the inability to detect statistical differences in expression of those transcripts. Nevertheless, we cannot discard the importance of these gene transcripts for oocyte competence.

The protein encoded by RAD50 is important for DNA double-strand break repair (Huang and Dynan, 2002). Since DNA repair is critical to maintain genomic integrity, it is probably required in the early embryo to correct damage inherited via the gametes, especially by the sperm nucleus, damage that arises during DNA replication, or damage that arises in response to environmental stress. Therefore, the newly fertilized embryo has to have the ability to sense and repair, at least some types of DNA damage (Zheng et al., 2005). In fact, it has been shown that treatment of zygotes with inhibitors of DNA repair can alter the amount and type of chromosomal aberrations, suggesting that several types of DNA lesions can be repaired in the zygote (Matsuda et al., 1989). This repairing activity has to be carried out by maternal mRNA and proteins stored before fertilization (Marchetti et al., 2004).

Cathepsin B is involved in the turnover of proteins and plays various roles in maintaining the normal metabolism of cells. It has been shown that cathepsin B, as well as other cathepsins, are produced in human and mouse ovaries and seems to be involved in follicle rupture (Oksjoki et al., 2001). In addition, it was reported that cathepsin B is present in the oocytes of primordial, primary and secondary follicles, and present in a higher amount in the oocyte of Graafian follicles. However, no function for cathepsin in the oocyte or embryos has been proposed. Our results showed the expression of cathepsin in the early cleaving embryos tended to be higher than in the late cleaving. In contrast, (Fair et al., 2004) using SSH to identify genes differentially expressed in early and late cleaving embryos found that cathepsin showed higher expression in the late cleaved embryos. The difference in the results could be explained by the method for the selection of the candidate. In our study, the selection was based on hybridization experiments using the library product as well as the early and late cleaving embryos as probes. In the mentioned study, the genes were selected directly from the results of the $\mathrm{SSH}$ and no differential hybridization was done, which could lead to the identification of false positives. In addition, the authors also raised the possibility that the original quality of the populations used for the SSH was not identical, which could also lead to the identification of false positives. Nevertheless, the higher expression of factors involved in protein regulation, such as cathepsins, may be important for the early embryos, since the embryo has to rely on nontranscriptional conditions until the MZT.

Among the chaperonines TCP1 is the most complex, not only because of its composition, but also of its function (for review see Valpuesta et al., 2002). TCP1 binds to new synthesized actin and tubulin and facilitate their folding (Yokota et al., 2000) and it is present in bovine oocytes and embryos (Sevigny et al., 1995). Considering that actin and tubulin networks are extensively reorganized in the oocyte after fertilization, and that TCP1 folds those proteins, it is possible that higher abundance of those transcripts would be necessary to allow correct cellular divisions. In addition, to the cytoskeletal function, it seems that TCP1 also has a role in transcription events to regulate the activity of histone deacetylase 3 (Guenther et al., 2002), which is involved in the control of gene expression in the early period of development (Segev et al., 2001; McGraw et al., 2003).

Beside the genes mentioned above we also quantified the expression of NCOR1, HUEL, ZNF403, STK6, EEF1A1, Hsp40, Hsp90, AKR1B1, PGRMC1, DMRT2, but the expression for all of them was not clearly different in early and late cleaving embryos. Those genes had been selected because they were considered promising candidates to have a role in oocyte competence due to their involvement in transcription modulation, translation, protein synthesis and regulation, cell signaling, differentiation, and antioxidant defense. Furthermore, some of those such as STK6 and AOP2 have already been reported to be present in bovine oocytes (Vigneron et al., 2004; Lequarre et al., 2004; Leyens et al., 2004).

For the majority of the genes studied, transcripts abundance was similar for early and late cleaving embryos. As stated above, given that the selection of gene candidates was based in the subtractive and hybridization studies, we could expect that the greater part of genes analyzed would show higher expression in the early competent embryos. Library subtractions associated with the microarray technique provide a very useful approach to screen potential candidates that are involved in a determined physiological status (for review see (Sirard et al., 2005). However, it is important to point out that the efficiency of that method is related to the amount of differences between the two tissues being compared. If there are few differences, we should expect more false positives. Furthermore, the procedure utilized for the microarray analysis can also affect the final results and it can be one of the limitations of the technique.

Although in the majority of the studies, the profiles found in microarray analysis, are confirmed by Q-PCR (Donnison and Pfeffer, 2004; Zeng et al., 2004; ElHalawany et al., 2005), however some studies have not found the same relationship. Similar to our results, some reports found that less than $30 \%$ of the genes 
selected after hybridization maintained the differential significance when the quantification by Q-PCR was performed (Sisco et al., 2003; Fair et al., 2004). These results support previous statements that the information obtained by microarray analysis requires a confirmation of the differential expression by other methods, such as Q-PCR. Moreover, care must be taken before doing creating assumptions about the functional significance of the mRNA levels of a specific gene. In a two-cell embryo, higher levels of mRNA may indicate that it has been degraded to a lesser extent, it has not been used and therefore has not been translated, or it has been transcribed in higher quantity and being stored for later use. Only after the evaluation of the corresponding protein content, is possible to relate the abundance of mRNA to its functional role in embryo development.

In conclusion, we have identified a few genes (YEAF, $\mathrm{IDH}, \mathrm{H} 2 \mathrm{~A}$ ) that were differentially expressed in the early cleaving embryos and their expression can be associated with competence. This contributes toward understanding the mechanism involved in bovine oocyte competence. Transcript levels provide a measure of RNA abundance, which can be affected not only by levels of transcription but also by RNA processing and degradation. Moreover, RNA abundance may not correspond to protein levels, nor does RNA provide information about protein modification, activity or location. Therefore, additional studies are needed to evaluate the role of those genes in the acquisition of developmental competence.

\section{ACKNOWLEDGMENTS}

We thank the Conselho Nacional de Desenvolvimento Científico e Tecnológico, CNPq, for financial supported the first author, under a Postdoctoral Scholarship and Dr. Susan Novak for reviewing the manuscript.

\section{REFERENCES}

Ali A, Sirard MA. 2002. The effects of 17beta-estradiol and protein supplement on the response to purified and recombinant follicle stimulating hormone in bovine oocytes. Zygote 10:65-71.

Brevini TA, Lonergan P, Cillo F, Francisci C, Favetta LA, Fair T, Gandolfi F. 2002. Evolution of mRNA polyadenylation between oocyte maturation and first embryonic cleavage in cattle and its relation with developmental competence. Mol Reprod Dev 63:510517.

Brevini-Gandolfi TA, Favetta LA, Mauri L, Luciano AM, Cillo F, Gandolfi F. 1999. Changes in poly(A) tail length of maternal transcripts during in vitro maturation of bovine oocytes and their relation with developmental competence. Mol Reprod Dev 52:427433.

Cetica P, Pintos L, Dalvit G, Beconi M. 2003. Involvement of enzymes of amino acid metabolism and tricarboxylic acid cycle in bovine oocyte maturation in vitro. Reproduction 126:753-763.

Cordoba M, Pintos L, Beconi MT. 2005. Differential activities of malate and isocitrate $\mathrm{NAD}(\mathrm{P})$-dependent dehydrogenases are involved in the induction of capacitation and acrosome reaction in cryopreserved bovine spermatozoa. Andrologia 37:40-46.

Coticchio G, Sereni E, Serrao L, Mazzone S, Iadarola I, Borini A. 2004. What criteria for the definition of oocyte quality? Ann N Y Acad Sci 1034:132-144.
Danen-van Oorschot AA, Voskamp P, Seelen MC, van Miltenburg MH Bolk MW, Tait SW, Boesen-de Cock JG, Rohn JL, Borst J, Noteborn MH. 2004. Human death effector domain-associated factor interacts with the viral apoptosis agonist Apoptin and exerts tumor-preferential cell killing. Cell Death Differ 11:564-573.

Dinnyes A, Lonergan P, Fair T, Boland MP, Yang X. 1999. Timing of the first cleavage post-insemination affects cryosurvival of in vitroproduced bovine blastocysts. Mol Reprod Dev 53:318-324.

Donnison M, Pfeffer PL. 2004. Isolation of genes associated with developmentally competent bovine oocytes and quantitation of their levels during development. Biol Reprod 71:1813-1821.

El-Halawany N, Ponsuksili S, Wimmers K, Gilles M, Tesfaye D, Schellander K. 2005. Quantitative expression analysis of blastocystderived gene transcripts in preimplantation developmental stages of in vitro-produced bovine embryos using real-time polymerase chain reaction technology. Reprod Fertil Dev 16:753-762.

Fair T, Murphy M, Rizos D, Moss C, Martin F, Boland MP, Lonergan P. 2004. Analysis of differential maternal mRNA expression in developmentally competent and incompetent bovine two-cell embryos. Mol Reprod Dev 67:136-144.

Favetta LA, Robert C, St John EJ, Betts DH, King WA. 2004. p66shc, but not p53, is involved in early arrest of in vitro-produced bovine embryos. Mol Hum Reprod 10:383-392.

Garcia E, Marcos-Gutierrez C, del Mar Lorente M, Moreno JC, Vidal M. 1999. RYBP, a new repressor protein that interacts with components of the mammalian Polycomb complex, and with the transcription factor YY1. EMBO J 18:3404-3418.

Guenther MG, Yu J, Kao GD, Yen TJ, Lazar MA. 2002. Assembly of the SMRT-histone deacetylase 3 repression complex requires the TCP-1 ring complex. Genes Dev 16:3130-3135.

Gutierrez-Adan A, Rizos D, Fair T, Moreira PN, Pintado B, de la Fuente J, Boland MP, Lonergan P. 2004. Effect of speed of development on mRNA expression pattern in early bovine embryos cultured in vivo or in vitro. Mol Reprod Dev 68:441-448.

Huang J, Dynan WS. 2002. Reconstitution of the mammalian DNA double-strand break end-joining reaction reveals a requirement for an Mre11/Rad50/NBS1-containing fraction. Nucleic Acids Res 30: 667-674.

Jennings GT, Sechi S, Stevenson PM, Tuckey RC, Parmelee D, McAlister-Henn L. 1994. Cytosolic NADP(+)-dependent isocitrate dehydrogenase. Isolation of rat cDNA and study of tissue-specific and developmental expression of mRNA. J Biol Chem 269:2312823134 .

Jeong YJ, Choi HW, Shin HS, Cui XS, Kim NH, Gerton GL, Jun JH. 2005. Optimization of real time RT-PCR methods for the analysis of gene expression in mouse eggs and preimplantation embryos. Mol Reprod Dev 71:284-289.

Koh HJ, Lee SM, Son BG, Lee SH, Ryoo ZY, Chang KT, Park JW, Park DC, Song BJ, Veech RL, Song H, Huh TL. 2004. Cytosolic NADP+dependent isocitrate dehydrogenase plays a key role in lipid metabolism. J Biol Chem 279:39968-39974.

Lee SM, Koh HJ, Park DC, Song BJ, Huh TL, Park JW. 2002. Cytosolic $\mathrm{NADP}(+)$-dependent isocitrate dehydrogenase status modulates oxidative damage to cells. Free Radic Biol Med 32:1185-1196.

Lequarre AS, Marchandise J, Moreau B, Massip A, Donnay I. 2003. Cell cycle duration at the time of maternal zygotic transition for in vitro produced bovine embryos: Effect of oxygen tension and transcription inhibition. Biol Reprod 69:1707-1713.

Lequarre AS, Traverso JM, Marchandise J, Donnay I. 2004. Poly(A) RNA is reduced by half during bovine oocyte maturation but increases when meiotic arrest is maintained with CDK inhibitors. Biol Reprod 71:425-431.

Leyens G, Verhaeghe B, Landtmeters M, Marchandise J, Knoops B, Donnay I. 2004. Peroxiredoxin 6 is upregulated in bovine oocytes and cumulus cells during in vitro maturation: Role of intercellular communication. Biol Reprod 71:1646-1651.

Lonergan P, Khatir H, Piumi F, Rieger D, Humblot P, Boland MP. 1999 Effect of time interval from insemination to first cleavage on the developmental characteristics, sex ratio and pregnancy rate after transfer of bovine embryos. J Reprod Fertil 117:159-167.

Lonergan P, Gutierrez-Adan A, Pintado B, Fair T, Ward F, Fuente JD, Boland M. 2000. Relationship between time of first cleavage and the expression of IGF-I growth factor, its receptor, and two housekeeping 
genes in bovine two-cell embryos and blastocysts produced in vitro. Mol Reprod Dev 57:146-152.

Lonergan P, Rizos D, Gutierrez-Adan A, Fair T, Boland MP. 2003. Oocyte and embryo quality: Effect of origin, culture conditions and gene expression patterns. Reprod Domest Anim 38:259-267.

Marchetti F, Bishop JB, Cosentino L, Moore D, 2nd, Wyrobek AJ. 2004. Paternally transmitted chromosomal aberrations in mouse zygotes determine their embryonic fate. Biol Reprod 70:616-624.

Marzluff WF, Duronio RJ. 2002. Histone mRNA expression: Multiple levels of cell cycle regulation and important developmental consequences. Curr Opin Cell Biol 14:692-699.

Matsuda Y, Seki N, Utsugi-Takeuchi T, Tobari I. 1989. X-ray- and mitomycin C (MMC)-induced chromosome aberrations in spermiogenic germ cells and the repair capacity of mouse eggs for the X-ray and MMC damage. Mutat Res 211:65-75.

McGraw S, Robert C, Massicotte L, Sirard MA. 2003. Quantification of histone acetyltransferase and histone deacetylase transcripts during early bovine embryo development. Biol Reprod 68:383-389.

Oksjoki S, Soderstrom M, Vuorio E, Anttila L. 2001. Differential expression patterns of cathepsins $\mathrm{B}, \mathrm{H}, \mathrm{K}, \mathrm{L}$ and $\mathrm{S}$ in the mouse ovary. Mol Hum Reprod 7:27-34.

Robert C, Barnes FL, Hue I, Sirard MA. 2000. Subtractive hybridization used to identify mRNA associated with the maturation of bovine oocytes. Mol Reprod Dev 57:167-175.

Robert C, McGraw S, Massicotte L, Pravetoni M, Gandolfi F, Sirard MA. 2002. Quantification of housekeeping transcript levels during the development of bovine preimplantation embryos. Biol Reprod 67:1465-1472

Rodriguez KF, Farin CE. 2004. Gene transcription and regulation of oocyte maturation. Reprod Fertil Dev 16:55-67.

Sanchez R, Marzluff WF. 2004. The oligo(A) tail on histone mRNA plays an active role in translational silencing of histone mRNA during Xenopus oogenesis. Mol Cell Biol 24:2513-2525.

Sawa C, Yoshikawa T, Matsuda-Suzuki F, Delehouzee S, Goto M, Watanabe H, Sawada J, Kataoka K, Handa H. 2002. YEAF1/RYBP and YAF-2 are functionally distinct members of a cofactor family for the YY1 and E4TF1/hGABP transcription factors. J Biol Chem 277:22484-22490.

Segev H, Memili E, First NL. 2001. Expression patterns of histone deacetylases in bovine oocytes and early embryos, and the effect of their inhibition on embryo development. Zygote 9:123-133.

Sevigny G, Kothary R, Tremblay E, De Repentigny Y, Joly EC, BiborHardy V. 1995. The cytosolic chaperonin subunit TRiC-P5 begins to be expressed at the two-cell stage in mouse embryos. Biochem Biophys Res Commun 216:279-283.
Sirard MA. 2001. Resumption of meiosis: Mechanism involved in meiotic progression and its relation with developmental competence. Theriogenology 55:1241-1254.

Sirard MA, Dufort I, Coenen K, Tremblay K, Massicotte L, Robert C. 2003. The use of genomics and proteomics to understand oocyte and early embryo functions in farm animals. Reprod Suppl 61:117129

Sirard MA, Dufort I, Vallee M, Massicotte L, Gravel C, Reghenas H, Watson AJ, King WA, Robert C. 2005. Potential and limitations of bovine-specific arrays for the analysis of mRNA levels in early development: Preliminary analysis using a bovine embryonic array. Reprod Fertil Dev 17:47-57.

Sisco B, Hagemann LJ, Shelling AN, Pfeffer PL. 2003. Isolation of genes differentially expressed in dominant and subordinate bovine follicles. Endocrinology 144:3904-3913.

Song JL, Wessel GM. 2005. How to make an egg: Transcriptional regulation in oocytes. Differentiation 73:1-17.

Sun L, Sun TT, Lavker RM. 1999. Identification of a cytosolic NADP+dependent isocitrate dehydrogenase that is preferentially expressed in bovine corneal epithelium. A corneal epithelial crystallin. J Biol Chem 274:17334-17341.

Valpuesta JM, Martin-Benito J, Gomez-Puertas P, Carrascosa JL, Willison KR. 2002. Structure and function of a protein folding machine: The eukaryotic cytosolic chaperonin CCT. FEBS Lett 529:11-16.

Vigneault C, McGraw S, Massicotte L, Sirard MA. 2004. Transcription factor expression patterns in bovine in vitro-derived embryos prior to maternal-zygotic transition. Biol Reprod 70:1701-1709.

Vigneron C, Perreau C, Dupont J, Uzbekova S, Prigent C, Mermillod P. 2004. Several signaling pathways are involved in the control of cattle oocyte maturation. Mol Reprod Dev 69:466-474.

Ward F, Rizos D, Corridan D, Quinn K, Boland M, Lonergan P. 2001 Paternal influence on the time of first embryonic cleavage post insemination and the implications for subsequent bovine embryo development in vitro and fertility in vivo. Mol Reprod Dev 60:47-55.

Yokota SI, Yanagi H, Yura T, Kubota H. 2000. Upregulation of cytosolic chaperonin CCT subunits during recovery from chemical stress that causes accumulation of unfolded proteins. Eur J Biochem 267:16581664.

Zeng F, Baldwin DA, Schultz RM. 2004. Transcript profiling during preimplantation mouse development. Dev Biol 272:483-496.

Zheng P, Schramm RD, Latham KE. 2005. Developmental regulation and in vitro culture effects on expression of DNA repair and cell cycle checkpoint control genes in rhesus monkey oocytes and embryos. Biol Reprod 72:1359-1369. 